\title{
Effect of silicate fertilization on soil and on palisade grass plants under grazing intensities ${ }^{1}$
}

\section{Pedro Henrique de Cerqueira Luz ${ }^{2}$, Letícia de Abreu Faria ${ }^{3}$, Felipe Barros de Macedo², Valdo Rodrigues Herling ${ }^{2}$, Antonio Batista Sanches ${ }^{2}$, Rosane Cláudia Rodrigues ${ }^{4}$}

\author{
1 Projeto financiado pela FAPESP. \\ 2 FZEA/USP, Dep. de Zootecnia, Av. Duque de Caxias-Norte, 225, 13630-900, Pirassununga, SP. \\ ${ }^{3}$ ESALQ/USP, Dep. de Solos e Nutrição de Plantas, Av. Pádua Dias, 11, Caixa Postal 9, 13418-900, Piracicaba, SP. \\ ${ }^{4}$ Universidade Federal do Maranhão - BR - 222, Km 04, Bairro Boa Vista, 65000-000, Chapadinha, MA.
}

\begin{abstract}
Application of calcium silicate ( $\mathrm{SiCa}$ ) as soil acidity corrective was evaluated in a Rhodic Hapludox soil with palisade grass conducted under pasture rotation system with different grazing intensities. Experimental design was complete randomized blocks with four grazing intensities - grazing intensities were imposed by forage supply (50, 100, 150 and $200 \mathrm{~kg} \mathrm{t}^{-1}$ of DM per LW) - in experimental plots with four replicates and, in the subplots, with seven doses of calcium silicate combined with lime: $0+0,2+0,4+0,6+0,2+4,4+2$ and $0+6 \mathrm{t} \mathrm{ha}^{-1}$, respectively. In the soil, it was evaluated the effect of four levels of calcium silicate $\left(0,2,4\right.$ and $\left.6 \mathrm{t} \mathrm{ha}^{-1}\right)$ at 45, 90, and 365 days at three depths $\left(0-10,10-20\right.$ and 20-40 cm) and at 365 days, it was included one level of lime $\left(6 \mathrm{t} \mathrm{ha}^{-1}\right)$. For determination of leaf chemical composition and silicate content in the soil, four levels of calcium silicate $\left(0,2,4\right.$ and $\left.6 \mathrm{t} \mathrm{ha}^{-1}\right)$ were evaluated at 45 and 365 days and at 45 days only for leaf silicate, whereas for dry matter production, all corrective treatments applied were evaluated in evaluation seasons. Application of calcium silicate was positive for soil chemical traits related to acidity correction $\left(\mathrm{pH}\left(\mathrm{CaCl}_{2}\right)\right.$, $\mathrm{Ca}, \mathrm{Mg}, \mathrm{K}, \mathrm{H}+\mathrm{Al}$ and $\left.\mathrm{V}\right)$, but the limestone promoted better results at 365 days. Leaf mineral contents were not influenced by application of calcium silicate, but there was an increase on silicate contents in leaves and in the soil. Dry matter yield and chemical composition of palisade grass improved with the application of correctives.
\end{abstract}

Key Words: calcium silicate, forage, limestone, silicon

\section{Introduction}

Pasture offers basic nutrition to the Brazilian herds. Most of the yield, quality and precocity of the final product depend on how pasture lands are exploited, therefore the establishment and management of pasture lands are extremely important to avoid land degradation and to assure sustainability without decreasing nutritional quality of meat products.

The chosen techniques determine the production dynamic and forage utilization; the unbalance may reduce the amount or quality of forage.

Brachiaria brizantha (Hoechst ex A. Rich.) Stapf. cv. Marandu (Marandu grass) is a rustic grass, with high yields of dry matter (DM) and crude protein (CP) in medium to low fertility soils. However, palisade grass pasture lands have been reported as decreasing production, which may have caused by decrease in soil fertility (Carvalho et al., 1991).

Soils in Brazilian Cerrado region (savannah-like environment) are, in general, strongly weathered and leached, dessilicated and poor in chemical bases. These soil clay fractions are dominated by kaolinite and iron and aluminum oxides, usually with a $\mathrm{Ki}$ index $\left(\mathrm{SiO}_{2} / \mathrm{Al}_{2} \mathrm{O}_{3}\right)$ smaller than 0.5 (Embrapa, 1982).

It is known that silicon enhance plant resistance to attack of insects, nematodes and patogens, and increases nutrition status, transpiration rate and possibly the photosynthesis of plants (Deren et al., 1994). The main properties of an adequate silicon source for agricultural application can be found in the Calcium and Magnesium Silicates ( $\mathrm{SiCa}$ ) obtained from waste, provided it is is free of heavy metals. Because this material is a mixture of $\mathrm{CaSiO}_{3}$ and $\mathrm{CaMgO}_{3}$, its use causes an increase in soil $\mathrm{pH}$ and in levels of Si, Ca and Mg in soil (Korndörfer et al., 2002).

The objective of the present study was to assess the use of calcium silicate in tropical soils and its impact on DM production, chemical and bromatologic composition of forrage, as well as soil chemical characteristics related to acidity correction.

\section{Material and Methods}

The experiment was carried out at Faculdade de Zootecnia e Engenharia de Alimentos, at Pirassununga 
campus of Universidade de São Paulo. The soil in the experimental area was Rhodic Hapludox (Soil Survey Staff, 2010; Latossolo Vermelho distroférrico típico; EMBRAPA, 2006).

The experimental area consisted of 16 experimental plots (paddocks) of 3,150 $\mathrm{m}^{2}$ each, managed with paddock rotation. Each plot was grazed for 7 days and fallowed for 28 days during the wet season (September to April) and for 56 days during the dry season (May to August).

Soil chemical analyses resulted in the following values: $\mathrm{pH}\left(\mathrm{CaCl}_{2}\right)=5.3$; soil organic matter $(\mathrm{SOM})=19.9 \mathrm{~g} \mathrm{~kg}^{-1}$; $\mathrm{K}=1.0 \mathrm{mmol}_{\mathrm{C}} \cdot \mathrm{dm}^{-3} ; \mathrm{Ca}=23 \mathrm{mmol}_{\mathrm{C}} \cdot \mathrm{dm}^{-3} ; \mathrm{Mg}=11 \mathrm{mmol}_{\mathrm{C}} \cdot \mathrm{dm}^{-3}$; $\mathrm{H}+\mathrm{Al}=22 \mathrm{mmol}_{\mathrm{C}} \cdot \mathrm{dm}^{-3} ; \mathrm{Al}=0 \mathrm{mmol}_{\mathrm{c}} \cdot \mathrm{dm}^{-3} ; \mathrm{CEC}=$ $56 \mathrm{mmol}_{\mathrm{c}} \cdot \mathrm{dm}^{-3} ; \mathrm{P}($ resin $)=9 \mathrm{mg} \cdot \mathrm{dm}^{-3} ; \mathrm{S}=4 \mathrm{mg} \cdot \mathrm{dm}^{-3} ; \mathrm{B}=$ $0.1 \mathrm{mg} \cdot \mathrm{dm}^{-3} ; \mathrm{Cu}=2.2 \mathrm{mg} \cdot \mathrm{dm}^{-3} ; \mathrm{Fe}=35 \mathrm{mg} \cdot \mathrm{dm}^{-3} ; \mathrm{Mn}=$ $4.3 \mathrm{mg} \cdot \mathrm{dm}^{-3} ; \mathrm{Zn}=0.6 \mathrm{mg} \cdot \mathrm{dm}^{-3} ; \mathrm{Si}(0-10 \mathrm{~cm})=23.8 \mathrm{mg} \cdot \mathrm{dm}^{-3}$; $\operatorname{Si}(10-20 \mathrm{~cm})=22.8 \mathrm{mg} \cdot \mathrm{dm}^{-3}$ and Base Saturation $(V)=59 \%$, which indicates the area could benefit from silicate fertilization.

In March 2002, calcium silicate (23\% of $\mathrm{SiO}_{2}, 41 \%$ of $\mathrm{CaO}, 11 \%$ of $\mathrm{MgO}, \mathrm{CCE}=100.7 \%$ and ECCE $85 \%$ ) was applied to soil using a volumetric dispenser coupled to a free fall spreader, on soil surface with no further incorporation.

During the wet season, phosphate fertilization (90 kg ha ${ }^{-1} \mathrm{P}_{2} \mathrm{O}_{5}$ ) was applied in a single dose and Nitrogen $\left(50 \mathrm{~kg} \mathrm{ha}^{-1} \mathrm{~N}\right)$ and Potassium $\left(25 \mathrm{~kg} \mathrm{ha}^{-1} \mathrm{~K}_{2} \mathrm{O}\right)$ replacement fertilization were applied on soil surface.

Two experimental designs were used in the experiment with soil chemical traits related to acidity neutralization at 0-10, 10-20 and 20-40 cm depths. The first experimental design used was a random block design in a $4 \times 4$ factorial arrangement in which plots were split over time $(45,90$ and 365 days after application) and four forage supplies (50, 100, 150 and $200 \mathrm{~kg} \mathrm{t}^{-1}$ of dry matter (DM) per live weight (LW)) and four rates of calcium silicate $\left(0,2,4\right.$ and $\left.6 \mathrm{t} \mathrm{ha}^{-1}\right)$, with four replications. The second design included one level of lime $\left(6.0 \mathrm{t} \mathrm{ha}^{-1}\right)$, resulting in a $4 \times 5$ factorial arrangement on day 365 .

The design for plant analysis was a random block design with four forrage supplies and four replications. However, for leaf chemical composition, the factorial arrangment was $4 \times 4$, considering four levels of calcium silicate (0, 2, 4 and $\left.6 \mathrm{tha}^{-1}\right)$ and four supplies of forage on day 45 and day 365. Chemcial analysis and DM yield, application of calcium silicate combined with lime were assessed according to the grazing rotation, at doses $0+0$, $2+0,4+0,6+0,2+4,4+2$ e $0+6$ tha $^{-1}$.

For silicon concentration in leaf and soil (at depths 0-10, 10-20 e 20-40 cm), it was used the random block design consisting of four supplies of forage, four levels of calcium silicate (0, 2, 4 and $\left.6 \mathrm{tha}^{-1}\right)$ and four replications on day 45 in plants and days 45 and 365 for soil.

Lime was used to increase the amount of calcium and to null calcium supply effect of calcium silicate and to allow the assessement of plant response to silicon.

To homogenize experimental plots, a high stocking rate was previously used in the experimental area, followed by a cut at $20 \mathrm{~cm}$ height to minimize variation in grass height.

During the experiment, two days before the access of animals, an indirect estimate of forage mass was done in each plot by using the rising plate matter (Neozeland make). The equipment was calibrated to fit the stocking rate at each supply of forage (treatment). A 100-cm ruler replaced the plate to estimate the forage DM in the residue, after the grazing period. The same procedure (use of ruler) was used at the pre grazing period, when material was collected for DM analysis. For DM yield estimation (pre and post grazing period), 30 points were measured (ruler and plate) in each treatment.

Leaf chemical analysis and silicon concentration was done in the third completely expanded grass leaf, as described in Malavolta et al. (1986), summing up $350 \mathrm{~g}$ of fresh leaf material per sample. Chemical analyses of crude protein (CP), neutral detergent fiber (NDF), acid detergent fiber (ADF), and lignin were done in all treatments, both in the rainy and in the dry season, in the above ground plant material (stalk + leaf). Estimate of total concentration was done based on the mean height of cut for each forage supply ( $50=10 \mathrm{~cm}, 100=20 \mathrm{~cm}, 150=30 \mathrm{~cm}$ e $200=40 \mathrm{~cm}$ ).

Chemcial analyses were done according to the following procedures: dry mass (DM), according to AOAC (1980); crude protein (CP) by the Microkjeldahl method (AOAC, 1980); neutral detergent fiber (NDF), acid detergent fiber (ADF) and lignin according to Goering \& Van Soest (1970). Soil macronutrients were measured according to Raij et al. (1996): potassium, calcium and magnesium were extracted by ion exchange resin and measured by emission spectrometry (potassium) and atomic absorption spectrometry (calcium and magnesium). Silicon on soil and in the plant was determined according to Korndörfer et al. (1999).

Statistical analysis was done by using the SAS (1989), algoritm SAS (1989) and treatment means were analyzed by using the Tukey test $(\mathrm{p}<0.10)$.

\section{Results and Discussion}

Use of calcium silicate resulted in soil acidity correction in the three depths evaluated, with variation of soil $\mathrm{pH}$ 
$\left(\mathrm{CaCl}_{2}\right)$ over time at the three depths evaluated (Table 1$)$. At 0-10 cm depth, average $\mathrm{pH}\left(\mathrm{CaCl}_{2}\right)$ increased by $11.7 \%$ $(\mathrm{p}<0.0001)$, but still within the high acidity range proposed by RAIJ et al (1996). The increase was by $10.61 \%$ in $10-20$ depth and $11.92 \%$ in $20-40 \mathrm{~cm}$ depth.

The interaction of time $\times$ forage supply at $0-10$ and 10-20 cm depths for $\mathrm{pH}\left(\mathrm{CaCl}_{2}\right)$, which had increasing values from day 45 to day 365 (after calcium silicate application), from all forage supply, as a result of reaction time of the calcium silicate.

The mean concentration of potassium in soil was influenced by time inasmuch as it changed from 1.3 to $2.1 \mathrm{mmol}_{\mathrm{C}} \cdot \mathrm{dm}^{-3}$ at $0-10$ depth and from 1.0 to $1.4 \mathrm{mmol}_{\mathrm{c}} \cdot \mathrm{dm}^{-3}$ at $10-20 \mathrm{~cm}$ depth. From day 45 to day 365, those concentrations changed from "low" to "medium", according to Raij et al. (1996), probably as a result of potassium fertilization done between the second and the third assessement because there was no difference among calcium silicate treatments.

The increase in calcium concentration in the soil over time was $64.7 \%$ for $0-10$ layer; $43.8 \%$ for $10-20$ and $54.5 \%$ for $20-40$ ( $\mathrm{p}<0.0001$; Table 1$)$.

There was calcium effect in soil only at 0-10 cm depth (Figure 1), because concentrations are considered "high" according to Malavolta et al. (1986), whereas at the $10-20 \mathrm{~cm}$ depth, concentrations are "medium" to "high" and at depth 20-40 cm, they are “medium”.

Magnesium concentration in soil increased over time at depths $0-10$ and $20-40 \mathrm{~cm}$. Mean variation was from $5 \mathrm{mmol}_{\mathrm{C}} \cdot \mathrm{dm}^{-3}$ on day 45 to $7 \mathrm{mmol}_{\mathrm{C}} \cdot \mathrm{dm}^{-3}$ on day 365 for $0-10 \mathrm{~cm}$ depth. These values are considered "medium" according to Malavolta et al. (1986). At 20-40 cm depth, the increase was from $3 \mathrm{mmol}_{\mathrm{c}} \cdot \mathrm{dm}^{-3}$ on day 45 to $4 \mathrm{mmol}_{\mathrm{c}} \cdot \mathrm{dm}^{-3}$ on day 365. Such results were not expected because the concentration of magnesium in the calcium silicate was small.

Table 1 - Values of $\mathrm{pH}\left(\mathrm{CaCl}_{2}\right)$, calcium and base saturation (V) at each soil depth, during the experiment period

\begin{tabular}{lccccc}
\hline $\begin{array}{l}\text { Depth } \\
(\mathrm{cm})\end{array}$ & $\begin{array}{c}\text { Evaluation } \\
\text { date (day) }\end{array}$ & $\begin{array}{c}\mathrm{pH} \\
\left(\mathrm{CaCl}_{2}\right)\end{array}$ & $\mathrm{V}(\%)$ & Calcium & $\mathrm{H}+\mathrm{Al}$ \\
\hline \multirow{2}{*}{$0-10$} & 45 & $4.5 \mathrm{~b}$ & $41.7 \mathrm{~b}$ & $17 \mathrm{c}$ & $40 \mathrm{a}$ \\
& 90 & $4.8 \mathrm{~b}$ & $42.2 \mathrm{~b}$ & $22 \mathrm{~b}$ & $35 \mathrm{~b}$ \\
& 365 & $5.0 \mathrm{a}$ & $52.1 \mathrm{a}$ & $28 \mathrm{a}$ & $32 \mathrm{~b}$ \\
$10-20$ & 45 & $4.5 \mathrm{~b}$ & $40.3 \mathrm{~b}$ & $16 \mathrm{~b}$ & $40 \mathrm{a}$ \\
& 90 & $4.8 \mathrm{a}$ & $40.7 \mathrm{~b}$ & $21 \mathrm{a}$ & $34 \mathrm{~b}$ \\
& 365 & $5.0 \mathrm{a}$ & $46.6 \mathrm{a}$ & $23 \mathrm{a}$ & $32 \mathrm{~b}$ \\
$20-40$ & 45 & $4.3 \mathrm{c}$ & $32.7 \mathrm{a}$ & $11 \mathrm{~b}$ & $43 \mathrm{a}$ \\
& 90 & $4.6 \mathrm{~b}$ & $31.1 \mathrm{a}$ & $14 \mathrm{~b}$ & $35 \mathrm{~b}$ \\
& 365 & $4.8 \mathrm{a}$ & $38.4 \mathrm{~b}$ & $17 \mathrm{a}$ & $34 \mathrm{~b}$ \\
\hline
\end{tabular}

Means with the same letters in each depth do not differ statistically $(\mathrm{p}<0.0001)$ by Tukey test.
Base saturation in soil (V) increased over time in all depths (Table 1), although values were considered "low" by Raij et al. (1996).

The mean values of $\mathrm{H}+\mathrm{AL}(\mathrm{p}<0.0001)$ decreased over time at the three depths (Table 1 ), although they were in the "medium" range proposed by Raij et al. (1996), and suggested a positive effect of calcium silicate to reduce the $\mathrm{H}+\mathrm{Al}$ levels, that is, as a soil acidity neutralizer.

The treatment with lime was included in the assessement of chemical soil properties only at the third evaluation date (day 365)

The liming treatment resulted in greater efficacy to increase mean $\mathrm{pH}\left(\mathrm{CaCl}_{2}\right)$ of soil (Table 2$)$ at $0-10 \mathrm{~cm}$ depth than did calcium silicate, which is not in agreement with the findings reported by Prado et al. (2001), whose results were similar for liming and calcium silicate application for soil acidity correction. However, the present study obtained significant changes in soil acidity with the application of calcium silicate alone, demonstrating its role as a soil acidity neutralizer. At greater depths, the mean values of $\mathrm{pH}\left(\mathrm{CaCl}_{2}\right)$ fit the "medium" to "high" soil acidity range, according to Raij et al. (1996).

Treatments did not affect concentration of potassium, being considered "medium" at 0-10 cm, "low" to "medium" at 20-40 cm and "low" at 20-40 cm depth (van Raij et al., 1996).

The use of the amendments (calcium silicate and lime) had significant effect on calcium concentration at 0-10 cm depth (Table 2), whose values are considered "high" (Malavolta et al., 1986). In deeper layers, the highest calcium values were observed as a consequence of liming, being interpreted as “medium” to "high” (Malavolta et al., 1986). Raij et al. (1996) and Prado et al. (2001) also reported

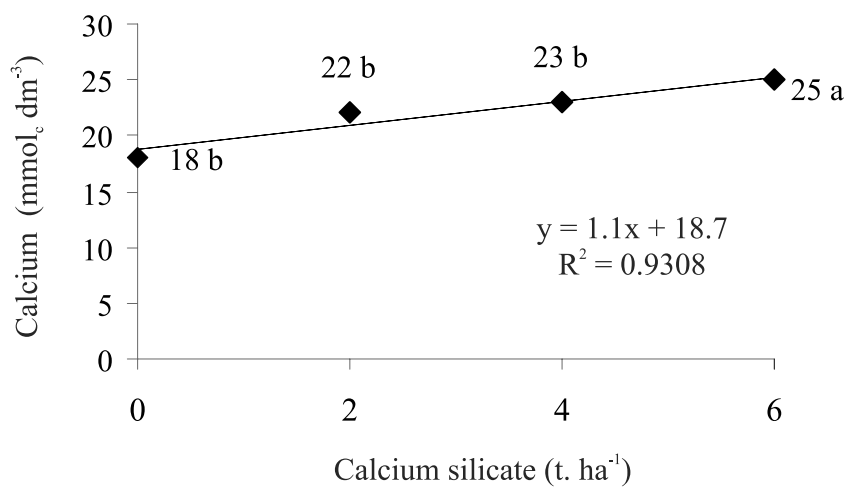

Means with the same letters at each depth do not differ statistically $(\mathrm{p}<0.0001)$ by Tukey test.

Figure 1 - Mean concentration of calcium $\left(\mathrm{mmol}_{\mathrm{c}} \cdot \mathrm{dm}^{-3}\right)$ at 0-10 cm depth as a function of calcium silicate doses. 
similar results for calcium silicate and lime, although the time span of their studies was shorter.

Mean concentration of magnesium changed with application of amendments, particularly for application of lime (0+6 t.ha-1), and values considered "high" for 0-10 cm depth; "medium" to "high" for 10-20 depth and "medium" for 20-40 cm (Table 2; Raij et al., 1996).

At $0-10 \mathrm{~cm}$ depth, the base saturation (V) was approximately $60 \%$ (Table 2 ), which is the value suggested by Werner et al. (1996) for palisade grass. This result showed the efficiency of calcium silicate and liming to increase base saturation. At deeper depths, values were classified as "low" to "medium" at 10-20 cm and "low" at 20-40 cm by van Raij et al. (1996). It should be highlighted the contrast between the amended treatments and the control, reinforcing the capacity of calcium silicate and mainly of lime to increase base saturation at depth.

Average values of $\mathrm{H}+\mathrm{Al}$ decreased to levels considered as "medium" and "low" (Malavolta et al., 1986) as a response to application of amendments (Table 2).

Silicon concentrations in soil changed over time and due to amendment application. At 0-10 cm depth, silicon concentration increased from $13.45 \mathrm{mg} \mathrm{dm}^{-3}$ to $15.73 \mathrm{mg} \mathrm{dm}^{-3}$ over time, meaning an increase of $16.95 \%$. Rate of 2 t.ha $^{-1}$ of calcium silicate increased silicon concentration in soil by $21 \%$, rate of 4 t.ha $^{-1}$ increased concentration by $27 \%$, and of 6 t.ha ${ }^{-1}$ it increased by $45 \%$. These changes were similar to those reported by Korndörfer \& Gascho (1999) on rice and Prado \& Fernandes (2001) on sugarcane.

The effect of forage supply was also detected at the 0-10 cm layer (Figure 2).

Silicon concentration in soil was greater for the forage supply of $200 \mathrm{~kg} \cdot \mathrm{t}^{-1}$ of dry matter per live weight as compared to the remaining treatments, probably due to a greater capacity to extract and export in an environment of small availability (50, 100 and $150 \mathrm{~kg} \cdot \mathrm{t}^{-1}$ of DM per LW) (Hodgson. 1990).

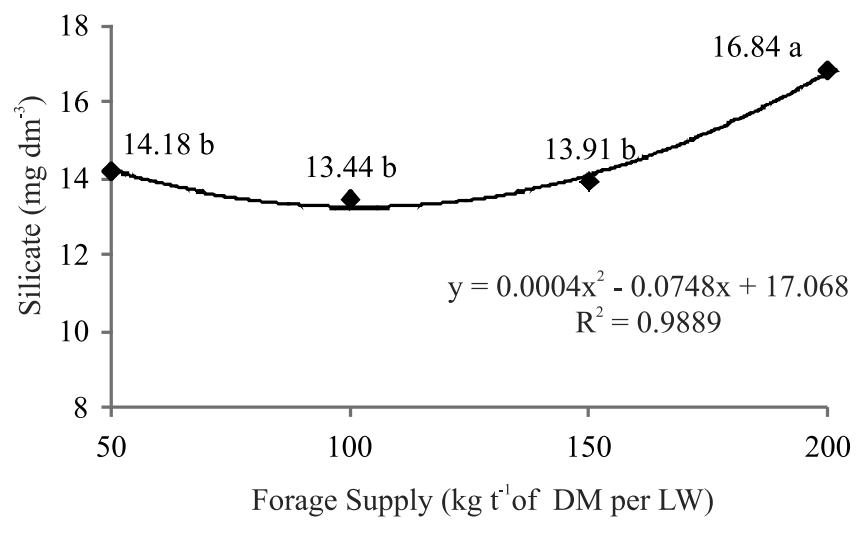

Means with the same letters in each depth do not differ statistically $(\mathrm{p}<0.0001)$ by Tukey test.

Figure 2 - Mean concentration of silicon $\left(\mathrm{mg} \cdot \mathrm{dm}^{-3}\right)$ at $0-10 \mathrm{~cm}$ depth for forage supply.

Table 2 - Values of $\mathrm{pH}\left(\mathrm{CaCl}_{2}\right)$, potassium, calcium and magnesium $\left(\mathrm{mmol}_{\mathrm{c}} \cdot \mathrm{dm}^{-3}\right)$, base saturation $(\%)$ and $\mathrm{H}+\mathrm{Al}\left(\mathrm{mmol}_{\mathrm{C}} \cdot \mathrm{dm}{ }^{-3}\right)$ at the three studied depths $(0-10 ; 10-20$ and $20-40 \mathrm{~cm})$

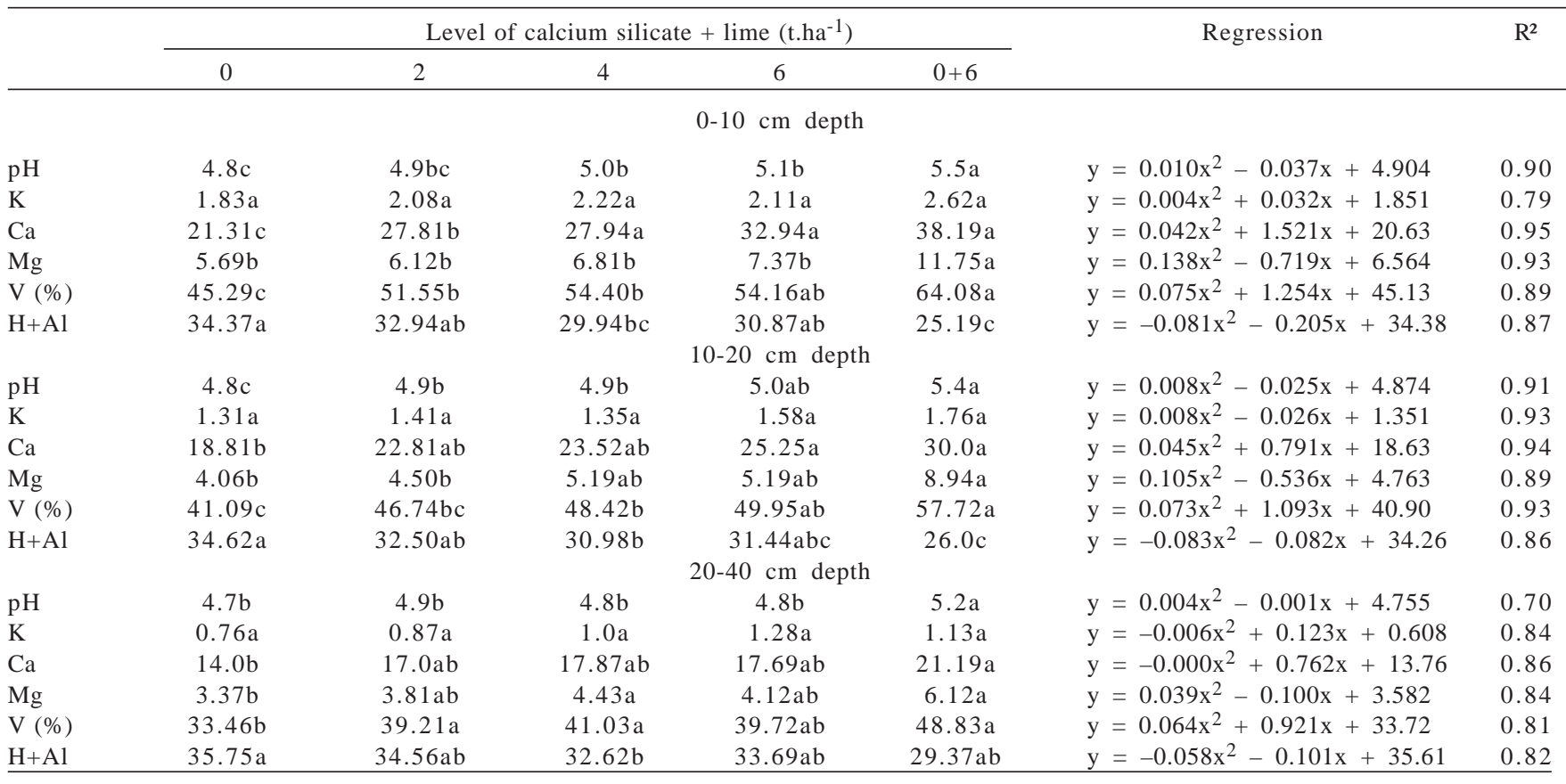

Means with the same letters at each depth do not differ statistically $(\mathrm{p}<0.0001)$ by Tukey test. 
Time effect was significant in deeper layers. Increase in the mean concentration of silicon from day 45 to day 365 was from 11.75 to $14.39 \mathrm{mg} \mathrm{dm}^{-3}$ at $10-20$ depth and from 10.90 to $15.41 \mathrm{mg} \mathrm{dm}^{-3}$ at the $20-40 \mathrm{~cm}$ depth. This result is in agreement with the idea that calcium silicate has a fast reaction in subsurface, even without its incorporation to the soil (Khalid et al., 1978; Korndörfer \& Gascho, 1999).

Silicon concentration in leaves at day 45 increased linearly with calcium silicate application rate (Table 3). These results are in agreement with the findings of Korndörfer \& Gascho (1999), working with rice. The remaining chemical elements measured in leaves did not show effect of amendments application, but they all resulted in effects over time (Table 4).

Forage supply influenced only $\mathrm{P}$ concentration in leaves, which showed smaller concentration $\left(1.68 \mathrm{~g} \mathrm{~kg}^{-1}\right)$ at treatment $20 \mathrm{~kg} \cdot \mathrm{t}^{-1}$ of dry matter per live weight, whereas the remaining did not differ among each other (from 1.76 to $1.92 \mathrm{~g} \mathrm{~kg}^{-1}$ ). This behavior may be related to changes in morphology of plants from treatments of greater forage supply, which showed smaller number of tillers, more elongated and thinner leafs and as a consequence, less amount of nutrients in younger leaves, as compared to the remaining treatments.

Potassium, magnesium and calcium were at adequate levels in leaves (Table 4), according to Malavolta et al. (1986). Decrease over time could be related to the fact that in the first measurement, the experimental area was not under grazing and as a consequence there was not nutrient export. In the second evaluation, in addition to export of nutrients, there was also the dilution effect due to plant growing and aging of sampled leaves.

Table 3 - Mean concentrations of silicon on soils $\left(\mathrm{mg}^{-\mathrm{dm}^{-3}}\right.$ ) and in the leaf $\left({\left.\mathrm{g} . \mathrm{kg}^{-1}\right)}^{-1}\right.$ in palisade grass pasture

\begin{tabular}{lcccc}
\hline $\begin{array}{l}\text { Depth } \\
(\mathrm{cm})\end{array}$ & \multicolumn{5}{c}{\begin{tabular}{c} 
Levels of calcium \\
\cline { 2 - 5 }
\end{tabular}} & 0 & 2 & 4 & 6 \\
\hline $0-10$ & $11.87 \mathrm{c}$ & $14.31 \mathrm{bc}$ & $15.03 \mathrm{ab}$ & $17.16 \mathrm{a}$ \\
$10-20$ & $10.90 \mathrm{c}$ & $12.56 \mathrm{bc}$ & $13.41 \mathrm{~b}$ & $15.41 \mathrm{a}$ \\
$20-40$ & $11.22 \mathrm{~b}$ & $12.16 \mathrm{ab}$ & $11.97 \mathrm{ab}$ & $13.34 \mathrm{a}$ \\
Leaf & $1.23 \mathrm{~b}$ & $1.32 \mathrm{ab}$ & $1.42 \mathrm{a}$ & $1.51 \mathrm{a}$ \\
\hline
\end{tabular}

Means with the same letters at each depth do not differ statistically $(\mathrm{p}<0.0001)$ by Tukey test.

Table 4 - Mean concentration of elements in leaves $\left(\mathrm{g} \cdot \mathrm{kg}^{-1}\right)$ on the evaluation dates

\begin{tabular}{lccccc}
\hline Evaluation date & $\mathrm{N}$ & $\mathrm{P}$ & $\mathrm{K}$ & $\mathrm{Mg}$ & $\mathrm{Ca}$ \\
\hline & \multicolumn{5}{c}{$\mathrm{g} . \mathrm{kg}^{-1}$} \\
\cline { 2 - 6 } 45 days & $16.8 \mathrm{a}$ & $1.66 \mathrm{~b}$ & $1.81 \mathrm{a}$ & $3.60 \mathrm{a}$ & $5.70 \mathrm{a}$ \\
365 days & $10.5 \mathrm{~b}$ & $1.95 \mathrm{a}$ & $1.31 \mathrm{~b}$ & $3.10 \mathrm{~b}$ & $4.20 \mathrm{~b}$ \\
\hline
\end{tabular}

Means with the same letters in each depth do not differ statistically $(\mathrm{p}<0.0001)$ by Tukey test.
The dry matter yield at the pre-grazing period had effect on amendments $x$ grazing rotation and forage supply $x$ grazing rotation interactions. The interaction of amendment application $\times$ grazing rotation (Figure 3 ) resulted in difference of control from the treatments with amendments at the first grazing period, which was concurrent with the period of more rain and higher temperature, and at the last grazing period, which was concurrent with the period of less rain and lower temperature. For the other periods, the behavior of the amendment treatments was similar.

The DM yield at the pre-grazing period increased with forage supply and decreased in the last grazing period (Figure 4) because tropical forage grasses are very sensitive to weather conditions (Whiteman, 1980).

For the DM yield, there was effect of forage supply and grazing rotation (Table 5).

Although the grazing period may be considered long (7 days), the potential yield of all forage supply treatments behave similarly during all evaluation dates, decreasing over time as a function of climatic conditions.

The amount of DM disappearance contrasted in all treatments with amendment application (Figure 5).

The disappearance of the above ground parts of grass also had effect of interaction of forage supply $x$ grazing periods. During the second grazing period (56 days) the greater disappearances values were observed in the treatments with the greater forage supply. Although with less grazing pressure, loss by trampling result in less efficiency of the DM use by the cattle (Hodgson, 1990).

At the third grazing period, an opposite behavior was observed. The smallest value of disappearance was at the

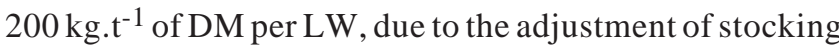
rate below the ideal rate, allowing faster recovery as compared to the remaining treatments. In the fourth period, the smallest value was observed at the forage supply of $50 \mathrm{~kg} \cdot \mathrm{t}^{-1}$ of DM per LW (Table 6).

Chemical analyses were performed in samples of palisade grass collected in the rainy season and in the dry season. The mean crude protein (CP) decreased from $6.66 \%$

Table 5 - Dry mass yield (kg.ha-1) at post-grazing for forage supply $\times$ grazing rotation interaction

\begin{tabular}{lcccc}
\hline $\begin{array}{l}\text { Grazing } \\
\text { rotation } \\
\text { (days) }\end{array}$ & \multicolumn{4}{c}{ Forage supply $\left(\mathrm{kg} . \mathrm{t}^{-1}\right.$ of DM per LW) } \\
\cline { 2 - 5 } & 50 & 100 & 150 & 200 \\
\hline 28 & $2537 \mathrm{Da}$ & $3336 \mathrm{Ca}$ & $3961 \mathrm{Ba}$ & $4688 \mathrm{Aa}$ \\
56 & $2056 \mathrm{Db}$ & $2760 \mathrm{Cb}$ & $3201 \mathrm{Bb}$ & $3492 \mathrm{Ab}$ \\
84 & $1607 \mathrm{Dc}$ & $2205 \mathrm{Cc}$ & $2618 \mathrm{Bc}$ & $3171 \mathrm{Ac}$ \\
140 & $715 \mathrm{Dd}$ & $1009 \mathrm{Cd}$ & $1304 \mathrm{Bd}$ & $1731 \mathrm{Ad}$ \\
\hline
\end{tabular}

Means with the same lower case letters in columns and capital letters in lines do not differ statistically $(\mathrm{p}<0.0001)$ by Tukey test. 
in the rainy season to $6.22 \%$ in the dry season, a value similar to those reported by Nunes et al. (1985), 6.21\% in the rainy season and $5.80 \%$ in the dry period in the whole plants.

Amendments application influenced CP mean values, which varied from $6.12 \%$ to $6.87 \%$ (Figure 5 ). The forage supply treatment of $50 \mathrm{~kg} . \mathrm{t}^{-1}$ of DM per LW had a $6.95 \%$ mean value of CP whereas the $20 \mathrm{~kg} \cdot \mathrm{t}^{-1}$ of DM per LW resulted in the smallest mean $(5.99 \%)$ and the remaining forage supply treatments did not differ from each other. The effect of forage supply on CP concentration can be explained by the greater elongation of stalks in the greater supply treatments, decreasing the concentration of CP (Hodgson, 1990).

The concentration of neutral detergent fiber (NDF) differed among evaluation periods only in forage supply treatments of 50 and $100 \mathrm{~kg} . \mathrm{t}^{-1}$ of DM per LW (Figure 6). The forage supply of $50 \mathrm{~kg} \cdot \mathrm{t}^{-1}$ of DM per LW during the rainy

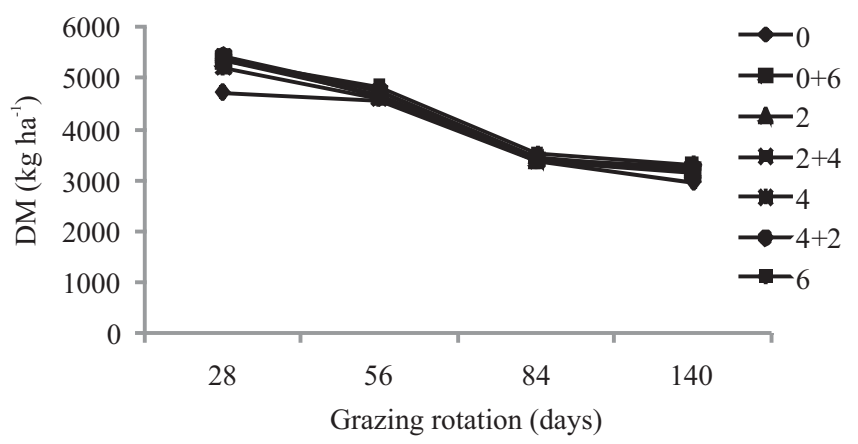

Figure 3 - Dry mass yield $\left(\mathrm{kg} \mathrm{ha}^{-1}\right)$ at pre-grazing for the interaction of amendment treatments $\times$ grazing rotation in days.

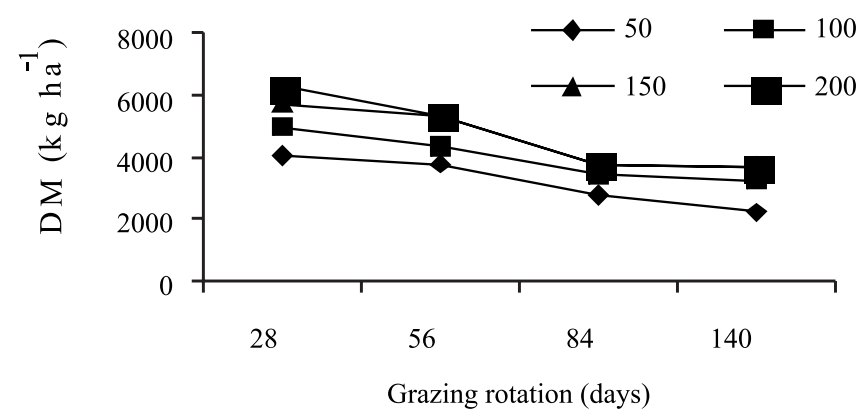

Figure 4 - DM yield $\left(\mathrm{kg} \mathrm{ha}^{-1}\right)$ at pre-grazing for grazing periods $\times$ forage supply interaction. season had the lowest concentration, confirming the influence of climatic conditions and forage supply on the composition of the cell wall (Hodgson, 1990).

The forage supply treatments 150 and $200 \mathrm{~kg} \cdot \mathrm{t}^{-1}$ of DM per LW (mean 80\%) were greater than the remaining treatments (mean 78\%). This result should be related to the cutting height of plants, which was different for each forage supply treatment, increasing as forage supply increased. The variation between the two seasons was $2 \%$, and the concentrations measured were similar to those reported by Nunes et al. (1985), but they challenged those reported by Soares Filho et al. (1992), who found greater concentrations during summer, intermediate during the spring and smaller concentrations during the winter $(\mathrm{p}<0.05)$, for palisade grass.

Mean values of acid detergent fiber (ADF) had linear positive effect of forage supply, particularly for 150 and $200 \mathrm{~kg} \cdot \mathrm{t}^{-1}$ of DM per LW which was $47.25 \%$ whereas the

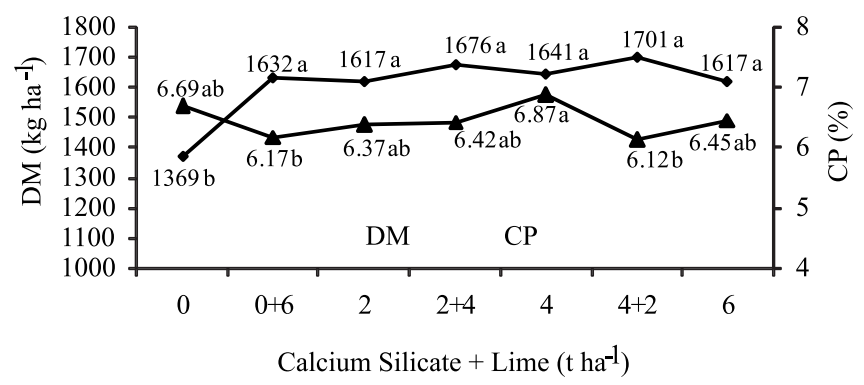

Means with the same letters an each depth do not differ statistically $(\mathrm{p}<0.0001)$ by Tukey test.

Figure 5 - Amount of dry mass disappeared (kg ha-1) and mean concentration of crude protein (CP) for treatments with calcium silicate + liming.

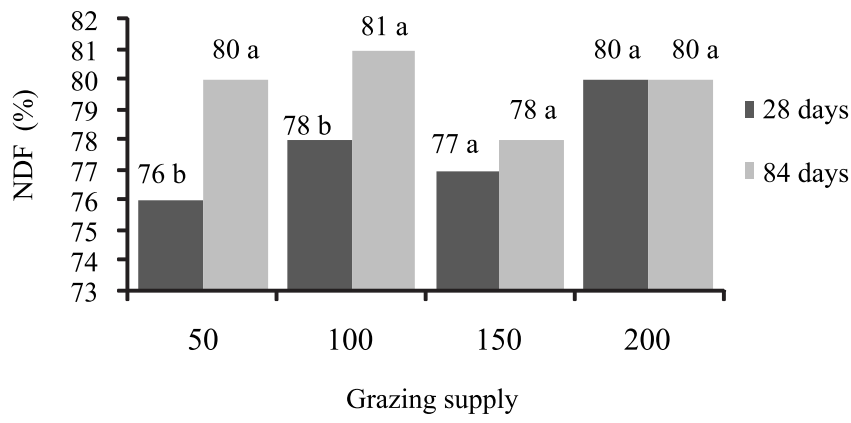

Means with the same letters at each depth do not differ statistically $(\mathrm{p}<0.0001)$ by Tukey test.

Figure 6 - Concentration of NDF for forage supply $\times$ evaluation period interaction. 
Table 6 - Amount of palisade grass DM dissapeared at 56, 84 and 140 days as a function of forage supply (kg.t $\mathrm{t}^{-1}$ of DM per LW)

\begin{tabular}{|c|c|c|c|}
\hline \multirow{3}{*}{ Forage supply } & \multicolumn{3}{|c|}{ Grazing rotation (days) } \\
\hline & 56 & 84 & 140 \\
\hline & \multicolumn{3}{|c|}{ kg.ha-1 DM } \\
\hline 100 & 1598.b & $1170 \mathrm{a}$ & $2200 a$ \\
\hline 150 & $2118 a$ & $1107 a$ & $2366 a$ \\
\hline 200 & $1843 \mathrm{ab}$ & $630 \mathrm{~b}$ & $1915 b$ \\
\hline
\end{tabular}

Means with the same letters at each depth do not differ statistically $(\mathrm{p}<0.0001)$ by Tukey test.

smallest value was observed in forage supply of $50 \mathrm{~kg} . \mathrm{t}^{-1}$ of DM per LW, $45.04 \%$. The mean value for a supply treatment of $100 \mathrm{~kg} \cdot \mathrm{t}^{-1}$ of DM per LW did not differ from 50 and 150 kg.t $\mathrm{t}^{-1}$ of DM per LW. These mean values were similar to those reported by Nunes et al. (1985). The increase trend in average ADF concurrent with forage supply may be related to the elongation of leaves, which decrease the leaf/stalk ratio.

Over time, the ADF concentration increased 3.8\%, from $45.53 \%$ at the first period to $47.25 \%$ at the third period of grazing. According to Hodgson (1990), this phenomenon is related to changes in the cell wall as a function of climatic conditions and plant nutrition (application of $\mathrm{N}$ fertilizer between evaluation dates).

The lignin concentration had effect only from the grazing periods. At the first evaluation the mean was $6.90 \%$ and at the third evaluation, 6.37\%. Therefore, it did not have a negative impact on CP accumulation (Hodgson, 1990).

\section{Conclusions}

Application of calcium silicate improves soil fertility properties and decreases soil acidity $\left(\mathrm{pH}\left(\mathrm{CaCl}_{2}\right), \mathrm{Ca}^{+2}\right.$, $\mathrm{Mg}^{+2}, \mathrm{~K}^{+}, \mathrm{H}+\mathrm{Al}$ and $\mathrm{V}$ ). However, liming present better results after 365 days. Rates from 2 to 6 t.ha ${ }^{-1}$ of calcium silicate increase concentrations of silicon in soil profile and leaves of palisade grass over time. The application of different rates of calcium silicate does not change the concentration of elements in leaves, but it increases them in soil and in the plant. Increasing rates of calcium silicate improves chemcial composition and dry mass production of pre-grazing palisade grass, as well as the leaf disappearance rate.

\section{Acknowledgements}

To FAPESP by providing fundings to this research and one Master Science scholarship.

\section{References}

ASSOCIATION OF OFFICIAL ANALYTICAL CHEMISTS - AOAC. Official methods of analysis. 13.ed. Washington: AOAC, 1980. 1015p.

CARVALHO, M.M.; MARTINS, C.E.; VERNEQUE, R.S. et al. Respostas de uma espécie de Brachiaria à fertilização com nitrogênio e potássio em um solo ácido. Revista Brasileira de Ciência do Solo, v.15, n.2, p.195-200, 1991.

DEREN, C.W.; DATNOFF, L.E.; ZINDER, G.H. et al. Silicon concentration disease response and yield components of rice genotypes grown on flooded organic Histosols. Crop Science, v.34, n.733-737, 1994.

EMPRESA BRASILEIRA DE PESQUISA AGROPECUÁRIA EMBRAPA. Serviço nacional de levantamento e conservação de solos. Manual de Métodos de Análise de Solo. Rio de Janeiro, 1979. 80p.

EMPRESA BRASILEIRA DE PESQUISA AGROPECUÁRIA EMBRAPA. Serviço nacional de levantamento e conservação de solos. Levantamento de média intensidade dos solos e avaliação de aptidão agrícola das terras do triângulo mineiro. Rio de Janeiro, 1982. 526p. (Boletim Técnico, 1).

GOERING, H.K.; VAN SOEST, P.J. Forage fiber analysis (apparatus, reagents, procedures and some applications). Washington, D.C.: USDA, 1970. (Agricultural Handbook, 379p).

HODGSON, J. Grazing management - science into practice. Essex: Longman Scientific e Technical, 1990. 203p.

KHALID, R.A.; SILVA, J.A.; FOX, R.L. Residual effects of calcium silicate in tropical soil. I-Fate of applied silicon during five years cropping. Soil Science Society of America Journal, v.42, p.89-94, 1978.

KORNDÖRFER, G.H.; ARANTES, V.A.; CORRÊA, G.F. et al. Efeito do silicato de cálcio no teor de silício no solo e na produção de grãos de arroz de sequeiro. Revista Brasileira de Ciência do Solo, v.23, p.623-629, 1999.

KORNDÖRFER, G.H.; GASCHO, G.J. Avaliação de fontes de silício para o arroz. In: CONGRESSO BRASILEIRO DE ARROZ IRRIGADO. 1; REUNIÃO DA CULTURA DO ARROZ IRRIGADO, 23., 1999, Pelotas. Anais... Pelotas: EMBRAPA Clima temperado, 1999. p.313-316.

KORNDÖRFER, G.H.; PEREIRA, H.S.; CAMARGO, M.S. Silicato de cálcio e magnésio na agricultura. Uberlândia: Universidade Federal de Uberlândia - Instituto de Ciências Agrárias, 2002. 15p. (Boletim Técnico, 1).

MALAVOLTA, E.; LIEM, T.H.; PRIMAVESI, A.C.P.A. Exigências nutricionais das plantas forrageiras. In: SIMPÓSIO SOBRE CALAGEM E ADUBAÇÃO DE PASTAGENS, 1., 1985, Nova Odessa. Anais... Piracicaba: POTAFOS, 1986. p.31-76.

NUNES, S.G.; BOOCK, A.; PENTEADO, M.I.O. et al. Brachiaria brizantha cv. Marandu. 2.ed. Campo Grande: EMBRAPA CNPGC, 1985. 31p. (Documentos, 21). 
PRADO, R.M.; FERNANDES, F.M.; NATALE, W. Uso agrícola da escória de siderurgia no Brasil: estudos na cultura da cana-de-açúcar. Jaboticabal: FUNEP, 2001. 67p.

PRADO, R.M.; FERNANDES, F.M. Resposta da cana-de-açúcar à aplicação da escória de siderurgia como corretivo de acidez do solo. Revista Brasileira de Ciência do Solo, v.25, p.201-209, 2001.

SOARES FILHO, C.V.; MONTEIRO, F.A.; CORSI, M. Recuperação de pastagens degradadas de Brachiaria decumbens. 1. Efeito de diferentes tratamentos de fertilização e manejo. Pasturas Tropicales, v.14, n.2, p.1-6, 1992.
SOIL SURVEY STAFF. Keys to soil taxonomy. 11.ed. Washington, D.C.: USDA-Natural Resources Conservation Service, 2010. 331p. STATISTICAL ANALYSES SYSTEM - SAS. SAS/STAT User's guide. Version 6. Cary: SAS Institute Inc., 1989. v.2. 446p.

van RAIJ, B.; CANTARELlA, H.; QUAGGIO, J.A. et al. Recomendações de adubação e calagem para o estado de São Paulo. 2.ed. Campinas. Instituto Agronômico de Campinas e Fundação IAC, 1996. 255p. (Boletim Técnico, 100).

WHITEMAN. P.C. Tropical pasture science. Oxford. University Press, 1980. 392p. 